\begin{tabular}{lcc}
\hline INESEG \\
INTERNATIONAL \\
$\begin{array}{c}\text { ENGINEERING, SCIENCE } \\
\text { AND EDUCATION } \\
\text { GROUP }\end{array}$ & Middle East Journal of Science \\
https://dergipark.org.tr/mejs \\
e-ISSN:2618-6136
\end{tabular}

Research Article

\title{
EVALUATION OF PHYTOCHEMICAL CONSTITUENTS IN THE WHOLE PLANT PARTS OF HEXANE EXTRACT OF SOME TRADITIONAL MEDICINAL PLANTS BY GC-MS ANALYSIS
}

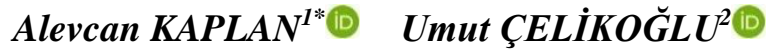 \\ ${ }^{1}$ Sason Vocational School, Department of Crop and Animal Production, Batman University, 72060 Batman, Turkey \\ ${ }^{2}$ Department of Chemistry, Faculty of Arts \& Science, Amasya University, 05100, Amasya, Turkey- Orcid No: \\ "Corresponding author:kaplanalevcan@gmail.com
}

\begin{abstract}
The aim of this study was to determine the phytochemical components from the hexane extract of some medicinal plants (Salvia palaestina Bentham, Alkanna trichophila var. mardinensis Hub-Mor. (an endemic variety), Scutellaria orientalis L. and to evaluate its biological activity by $G C$ $M S$ analysis. The chemical components in this hexane extract were subjected to the Agilent 7890B GC5977MSD model Gas Chromatography - Mass Spectrometric analysis. Thirty-two chemical compounds have been identified in the plant extracts. This definition is based on the peak area, retention time, molecular weight, and molecular formula. In this research, Bis (2-ethylhexyl) phthalate, tricosane, docosane, transcaryophyllene, nonacosane, beta-Cubebene, Trichlorfon, Naphthalene, 1,2,3,4,4a, 5,6,8a-octahydro-4a, 8-dimethyl -2- (1-methylet henyl) -, [2R, 3-Aminophenol were found predominantly compounds in extracts. These compounds, which we identified in our study, have a wide range of biological activity and have been found to have high therapeutic value. They are candidate plants to be medicines with various active ingredient content.
\end{abstract}

Keywords: GC-MS analysis, medicinal plants, phytochemical constituents, therapeutic

Received: December 5, 2020

Accepted: December 29, 2020

\section{Introduction}

Turkey is among the richest countries in the world in terms of plant diversity. Although it is about 15 times smaller than Europe in terms of surface area, it has plant diversity as much as European continental flora in terms of flora. The main reasons for this wealth are as follow; a variety of climates, topographical diversity with marked changes in ecological factors over short distance, geological and geomorphic variation, a range of aquatic environments such as seas, lakes, and rivers, altitude variations from sea level to 5000 [1]. The total number of species and subspecies taxa in our country is 11 707 including the foreign origin and cultivated plants [2]. It is estimated that the type of plants used for medicinal purposes is around 1000 [3]. Medicinal plants are part of the nature pharmacy. Despite important advances in medicine, people have sought healing from time to time and have never stopped using medicinal plants as a result of their experience for centuries. Especially the emergence of side effects of synthetic and chemical drugs has increased the use of medicinal plants. Medicinal plants spice, pharmaceutical industry, soft drink, perfume, soap, confectionery, cosmetics, toothpaste, chewing gum, healing and relaxing tea manufacture, essential oil, aroma, etc. it is used in many fields [4]. In 
addition, natural products, pure compounds or standard herbal extracts offer unlimited opportunities to obtain new medicines due to the unique availability of chemical diversity. The knowledge gained about the chemical constituents of plants will be more useful in discovering the true value of folk remedies [5].

In the present study, it was aimed to determine the preliminary phytochemical analysis of Salvia palaestina Bentham, Alkanna trichophila var. mardinensis Hub.-Mor. (an endemic variety), Scutellaria orientalis $\mathrm{L}$. which has not been studied before, which grows in the untouched Mount Raman, Batman. For this reason, phytochemical screening of the species in question during current research is carried out in order to analyze the presence of chemical compounds, which are secondary metabolites, in order to suggest their application in the pharmaceutical industry.

\section{Materials and Methods}

\subsection{Collection and identification of plant samples}

The plant samples were collected from the natural habitat of the Batı Raman campus in Batman University. Voucher specimens have been deposited at the Batman University (voucher no. 2020/015, 2020/016, and 2020/014, respectively) (Figure 1). The taxonomical identity of the plant was confirmed by Dr. Alevcan Kaplan. This identification was made using, Flora of Turkey, Volume 6-7. [6,7]. The collected, whole parts of plants were washed to remove dust and other plant materials and were shade dried at room temperature. The dried leaves and flowers were then ground to a powder using an electric grinder and kept separately for future research in lidded containers.

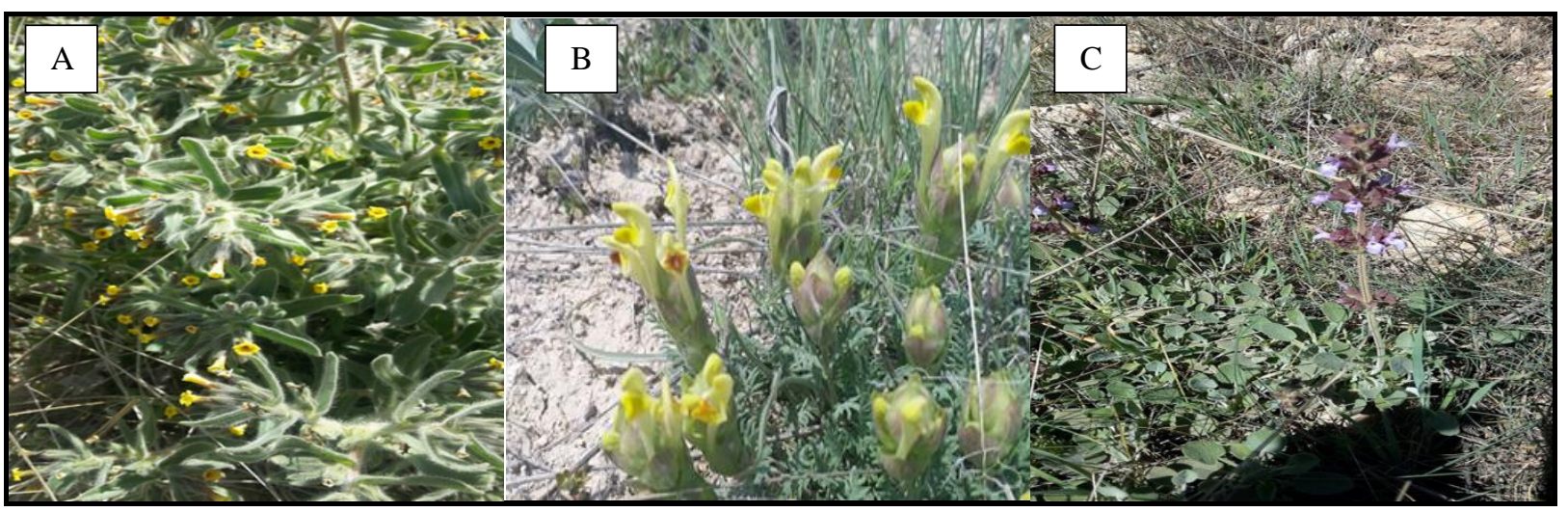

Figure 1. General view of plants (A: Alkanna trichophila var. mardinensis B: Scutellaria orientalis C: Salvia palaestina) Photo: A. Kaplan

\subsection{Plant Sample Preparation for GC-MS}

The $\mathrm{n}$-hexane extract of the plants was obtained using the Soxhlet extractor. $10 \mathrm{~g}$ of powdered plant samples were put into the Soxhlet extractor and the required amount was obtained by repeatedly using $100 \mathrm{ml}$ of $\mathrm{n}$-hexane (boiling point about $40-60^{\circ} \mathrm{C}$ ) as solvent extract for four (4) hours. The oil was kept in a refrigerator without further processing until required for analysis.

\subsection{GC-MS Data Analysis Condition}

Gas chromatography-Mass spectrometry (GC-MS) analysis of n-hexane extracts of plants was performed using Agilent 7890B GC- 5977MSD model with the column length (30 m), diameter (250 $\mu \mathrm{m})$, and film thickness $(0.25 \mu \mathrm{m})$ was used with Helium ( $99.9995 \%$ purity) as the carrier gas, operat- 
ing in electron impact mode at $70 \mathrm{eV}$. and the GS-MS condition during the research is following conditions. Injector temperature was $250{ }^{\circ} \mathrm{C}$, ion-source temperature $200{ }^{\circ} \mathrm{C}$ split flow was $2.4 \mathrm{ml} / \mathrm{min}$. The oven temperature was programmed $120^{\circ} \mathrm{C}\left(5^{\circ} \mathrm{C} / \mathrm{min}, 7 \mathrm{~min}\right), 150{ }^{\circ} \mathrm{C}\left(5^{\circ} \mathrm{C} / \mathrm{min}, 7 \mathrm{~min}\right), 200{ }^{\circ} \mathrm{C}$ $\left(5{ }^{\circ} \mathrm{C} / \mathrm{min}, 7 \mathrm{~min}\right), 220^{\circ} \mathrm{C}\left(5^{\circ} \mathrm{C} / \mathrm{min}, 7 \mathrm{~min}\right), 240{ }^{\circ} \mathrm{C}\left(5{ }^{\circ} \mathrm{C} / \mathrm{min}, 7 \mathrm{~min}\right), 250{ }^{\circ} \mathrm{C}\left(5^{\circ} \mathrm{C} / \mathrm{min}, 7 \mathrm{~min}\right)$. The split flow was $2.4 \mathrm{ml} / \mathrm{min}$ and an injection volume of $1 \mu 1$ was employed (split ratio of 2:1). The hexane extract of plants was injected with syringe manually for total bioactive components of leaf and flower samples. Total GC running time is $68 \mathrm{~min}$.

\subsection{Identification of constituents}

The identity of the constituents in the extract is assigned by comparison of retention times and mass spectra with those stored in the computer fragmentation models library and also with electronic libraries (W9N11.L, MPW2011.L and RTLPEST3.L). Electronic Libraries sources were also used to match the components identified from the plant material. The name, the nature of the compound, molecular weight, molecular formula of the components of the test materials have been confirmed.

\section{Results and Discussion}

Traditional medicine and food in many plants used Turkey is one of the world's richest countries in terms of genetic diversity. The main reasons for the richness of plant species in Turkey are different climates and soil types and topography as a result of other environmental conditions. In Anatolia folk medicine, medicinal plants have an important place in the field of health both in the world and in our country. Therefore, it is important to conduct research on such plants containing a variety of phytochemicals as it has a high potential to result in cost-effective drug intervention with fewer side effects.

In this study, phytochemical constituents of Alkanna trichophila var. mardinensis, Scutellaria orientalis and Salvia palaestina were identified and characterized respectively. In this respect, nine compounds were identified in Alkanna trichophila var. mardinensis by GC-MS analysis (Table 1). The list of phytochemical compounds from the plant sample is tabulated in Table 1 with retention time, area, and area percentage. The chromatogram information for the sample is given in Figure 2. The retention time taken by the bioactive compounds of the plant sample varied from 31.183 to 65.168. It was found that main constituents of sample were 13-Octadecenal (1.84\%), Tetradecanal (0.65\%), Dinocap II (3.32 \%), Bis(2-ethylhexyl) pht-halate (60.60\%), alpha-Amyrin (3.43\%), Metolcarb (1.58 \%), Tricosane (12.44 \%), Octacosane (7.50 \%), Docosane (8.64 \%). The compound phenol 13-Octadecenal is known for its sex pheromone, antimicrobial activity [8,9]. Tetradecanal is known for immunotoxicity activity. bacterial bioluminescence, sex pheromone Heliothis virescens (F.) females [10, 11, 12]. Dinocap II has been reported to contact fungicide used to control powdery mildew on many crops and is also used as a non-systemic acaricide [13]. Bis (2-ethylhexyl) pht-halate has a role as an apoptosis inhibitor, an androstane receptor agonist and a plasticiser. Moreover, it has an anti-leukaemic, antimutagenic, antimicrobial, and cytotoxic activity [14,15]. Alpha-Amyrin is known for attenuates orofacial pain, reducing hyperalgesia, anti-inflammatory effects [16,17]. Metolcarb is an insecticide [18]. Tricosane has been reported to bear antimicrobial activity and influence host egg parasitisation by Trichogramma [19,20]. Octacosane is known to possess antimicrobial, antioxidant, and antiinflammatory [21,22]. Docosane is reported to aid in host egg parasitization that can be used as a biocontrol agent, antimicrobial, antioxidant, and functional food nutraceutical applications [23,24,25]. In light of this information, it has been determined that the plant constituting our experimental material 
contains different amounts of bioactive components with various therapeutic effects. The potential of the plant to be used in the treatment of diseases such as antileukemia, which is the most common disease of today, has been revealed, especially due to its high content of Bis (2-ethylhexyl) pht-halate. [15] reported that Bis (2-ethylhexyl) pht-halate isolated from Aloe vera L. showed anti-leukemic and antimutagenic effects (Salmonella typhimurium TA98 and TA100 strains). [26] found that di- (2ethylhexyl) phthalate (DEHP) isolated from Calotropis gigantea L. flowers had an antitumor effect. We determined that our plant in question has a feature that can be used in the treatment of these diseases.

Table 1. Phytochemical constituents of Alkanna trichophila var. mardinensis by GC-MS

\begin{tabular}{lcccccc}
\hline No & $\begin{array}{c}\text { Name of the } \\
\text { compound }\end{array}$ & $\begin{array}{c}\text { Molecular } \\
\text { formula }\end{array}$ & $\begin{array}{c}\text { Molecular } \\
\text { weight }\end{array}$ & RT & $\begin{array}{c}\text { Peak } \\
\text { area(\%) }\end{array}$ & $\begin{array}{c}\text { Nature of the } \\
\text { compound }\end{array}$ \\
\hline $\mathbf{1}$ & 13-Octadecenal, & $\mathrm{C}_{18} \mathrm{H}_{34} \mathrm{O}$ & $266.5 \mathrm{~g} / \mathrm{mol}$ & 31.183 & 1.84 & - \\
$\mathbf{2}$ & Tetradecanal, & $\mathrm{C}_{14} \mathrm{H}_{28} \mathrm{O}$ & $212.37 \mathrm{~g} / \mathrm{mol}$ & 31.884 & 0.65 & $\begin{array}{c}\text { fatty aldehyde } \\
\text { enoate ester } \\
\text { phthalate ester }\end{array}$ \\
$\mathbf{3}$ & Dinocap II, & $\mathrm{C}_{18} \mathrm{H}_{24} \mathrm{~N}_{2} \mathrm{O}_{6}$ & $364.39 \mathrm{~g} / \mathrm{mol}$ & 42.215 & 3.32 & \\
$\mathbf{4}$ & Bis(2-ethylhexyl) & $\mathrm{C}_{24} \mathrm{H}_{38} \mathrm{O}_{4}$ & $390.6 \mathrm{~g} / \mathrm{mol}$ & 50.157 & 60.60 & pentacyclic triterpenoid \\
& phthalate, & & & & & carbamate ester \\
$\mathbf{5}$ & alpha-Amyrin, & $\mathrm{C}_{30} \mathrm{H}_{50} \mathrm{O}$ & $426.7 \mathrm{~g} / \mathrm{mol}$ & 53.434 & 3.43 & N-Alkanes \\
$\mathbf{6}$ & Metolcarb & $\mathrm{C}_{9} \mathrm{H}_{11} \mathrm{NO}_{2}$ & $165.19 \mathrm{~g} / \mathrm{mol}$ & 54.608 & 1.58 & N-Alkanes \\
$\mathbf{7}$ & Tricosane & $\mathrm{C}_{23} \mathrm{H}_{48}$ & $324.6 \mathrm{~g} / \mathrm{mol}$ & 56.754 & 12.44 & N-Alkanes \\
$\mathbf{8}$ & Octacosane & $\mathrm{C}_{28} \mathrm{H}_{58}$ & $394.8 \mathrm{~g} / \mathrm{mol}$ & 57.055 & 7.50 & 8.64 \\
$\mathbf{9}$ & Docosane & $\mathrm{C}_{22} \mathrm{H}_{46}$ & $310.6 \mathrm{~g} / \mathrm{mol}$ & 65.168 & & \\
\hline
\end{tabular}

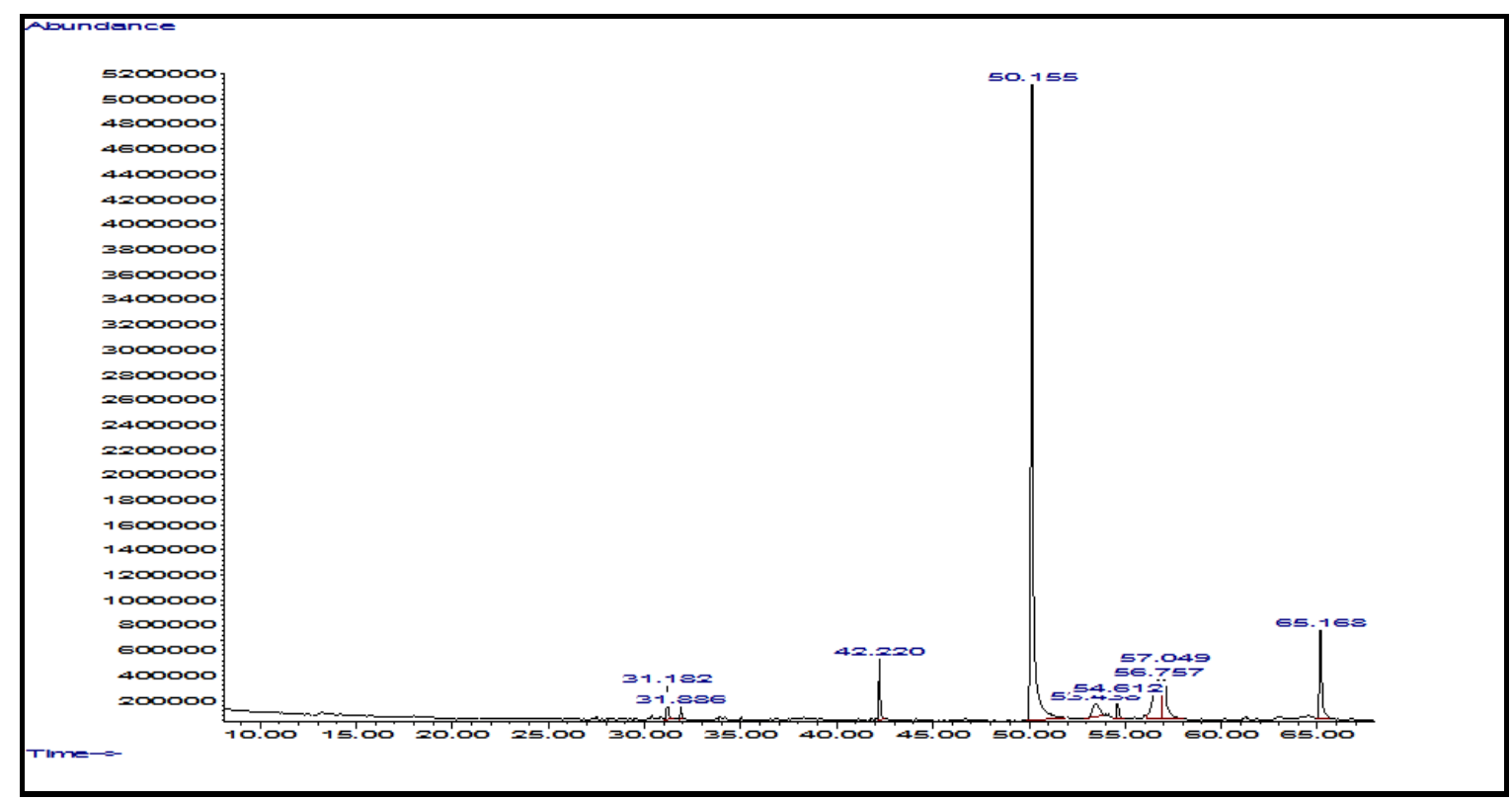

Figure 2. GC- MS chromatogram of the hexane fraction of compounds from Alkanna trichophila var. mardinensis

Secondly, eleven compounds were identified in Scutellaria orientalis by GC-MS analysis (Table 2). The list of phytochemical compounds from the plant sample is tabulated in Table 2 with retention time, area, and area percentage. The chromatogram information for the sample is given in Figure 3. The retention time taken by the bioactive compounds of the plant sample varied from 0.93 to 28.83 . It was found that main constituents of sample were 2-Ethyl-1,3-hexanediol (2.97\%), Tryclopyrbutoxyethyl $(1.66 \%)$, trans-Caryophyllene $(28.83 \%)$, beta-Cubebene $(6.46 \%)$, Tris(2-butoxyethyl) phosphate $(0.93 \%)$, Diisobutyl phthalate (0.65\%), Eicosane (2.44 \%), 1-Triacontanol (3.48 \%), Heptacosane $(5.19 \%)$, 1-Heptacosanol (5.13\%), Nonacosane (16.14 \%). 2-Ethyl-1,3-hexanediol has an an- 
tiparasitic, insecticidal, and repellent, ectoparasiticidal effect [27]. Tryclopyrbutoxyethyl is known to pesticide [28]. Trans-caryophyllene is also known as antibacterial and antifungal [29]. Beta-Cubebene has been reported that neuroprotective effects [30]. Tris (2-butoxyethyl) phosphate (TBEOP) is an organophosphate [31]. Diisobutyl phthalate also known proliferation and differentiation of primary osteoblasts, antioxidant, and free radical scavenging activities [32,33]. Eicosane has been reported that an antitumor activity [34]. 1-Triacontanol (TRIA) is a growth regulator for plants [35]. Heptacosane has shown antioxidant, antibacterial, antimalarial, antidermatophytic effects [36,37,38]. 1-Heptacosanol is known for its antimicrobial activity [39]. Nonacosane has also known as celidoniol deoxy antibacterial and anti-inflammatory $[40,41]$. It is clear that the plant in question contains bioactive components with broader effects. Our study results support the potential of the plant to be used ethnobotanically in the region.

Table 2. Phytochemical constituents of Scutellaria orientalis by GC-MS

\begin{tabular}{|c|c|c|c|c|c|c|}
\hline No & $\begin{array}{l}\text { Name of the } \\
\text { compound }\end{array}$ & $\begin{array}{l}\text { Molecular } \\
\text { formula }\end{array}$ & $\begin{array}{c}\text { Molecular } \\
\text { weight }\end{array}$ & RT & $\begin{array}{c}\text { Peak } \\
\text { area }(\%)\end{array}$ & $\begin{array}{l}\text { Nature of the } \\
\text { compound }\end{array}$ \\
\hline 1 & 2-Ethyl-1,3-hexanediol & $\mathrm{C}_{8} \mathrm{H}_{18} \mathrm{O}_{2}$ & $146.23 \mathrm{~g} / \mathrm{mol}$ & 9.160 & 2.97 & Aliphatic alcohol \\
\hline 2 & Tryclopyrbutoxyethyl & $\mathrm{C}_{13} \mathrm{H}_{16} \mathrm{Cl}_{3} \mathrm{NO}_{4}$ & $356.6 \mathrm{~g} / \mathrm{mol}$ & 10.405 & 1.66 & - \\
\hline 3 & trans-Caryophyllene & $\mathrm{C}_{15} \mathrm{H}_{24}$ & $204.35 \mathrm{~g} / \mathrm{mol}$ & 11.607 & 28.83 & Bicyclic sesquiterpene \\
\hline 4 & beta-Cubebene & $\mathrm{C}_{15} \mathrm{H}_{24}$ & $204.35 \mathrm{~g} / \mathrm{mol}$ & 11.879 & 6.46 & Tricyclic sesquiterpene \\
\hline 5 & $\begin{array}{c}\text { Tris(2-butoxyethyl) } \\
\text { phosphate }\end{array}$ & $\mathrm{C}_{18} \mathrm{H}_{39} \mathrm{O}_{7} \mathrm{P}$ & $398.5 \mathrm{~g} / \mathrm{mol}$ & 14.469 & 0.93 & - \\
\hline 6 & Diisobutyl phthalate & $\mathrm{C}_{16} \mathrm{H}_{22} \mathrm{O}_{4}$ & $278.34 \mathrm{~g} / \mathrm{mol}$ & 27.062 & 0.65 & Phthalate ester \\
\hline 7 & Eicosane & $\mathrm{C}_{20} \mathrm{H}_{42}$ & $282.5 \mathrm{~g} / \mathrm{mol}$ & 50.143 & 2.44 & N-Alkanes \\
\hline 8 & 1-Triacontanol & $\mathrm{C}_{30} \mathrm{H}_{62} \mathrm{O}$ & $438.8 \mathrm{~g} / \mathrm{mol}$ & 56.010 & 3.48 & Fatty alcohol \\
\hline 9 & Heptacosane & $\mathrm{C}_{27} \mathrm{H}_{56}$ & $380.7 \mathrm{~g} / \mathrm{mol}$ & 57.055 & 5.19 & N-Alkanes \\
\hline 10 & 1-Heptacosanol & $\mathrm{C}_{27} \mathrm{H}_{56} \mathrm{O}$ & $396.7 \mathrm{~g} / \mathrm{mol}$ & 64.152 & 5.13 & Fatty alcohol \\
\hline 11 & Nonacosane & $\mathrm{C}_{29} \mathrm{H}_{60}$ & $408.8 \mathrm{~g} / \mathrm{mol}$ & 65.154 & 16.14 & N-Alkanes \\
\hline
\end{tabular}

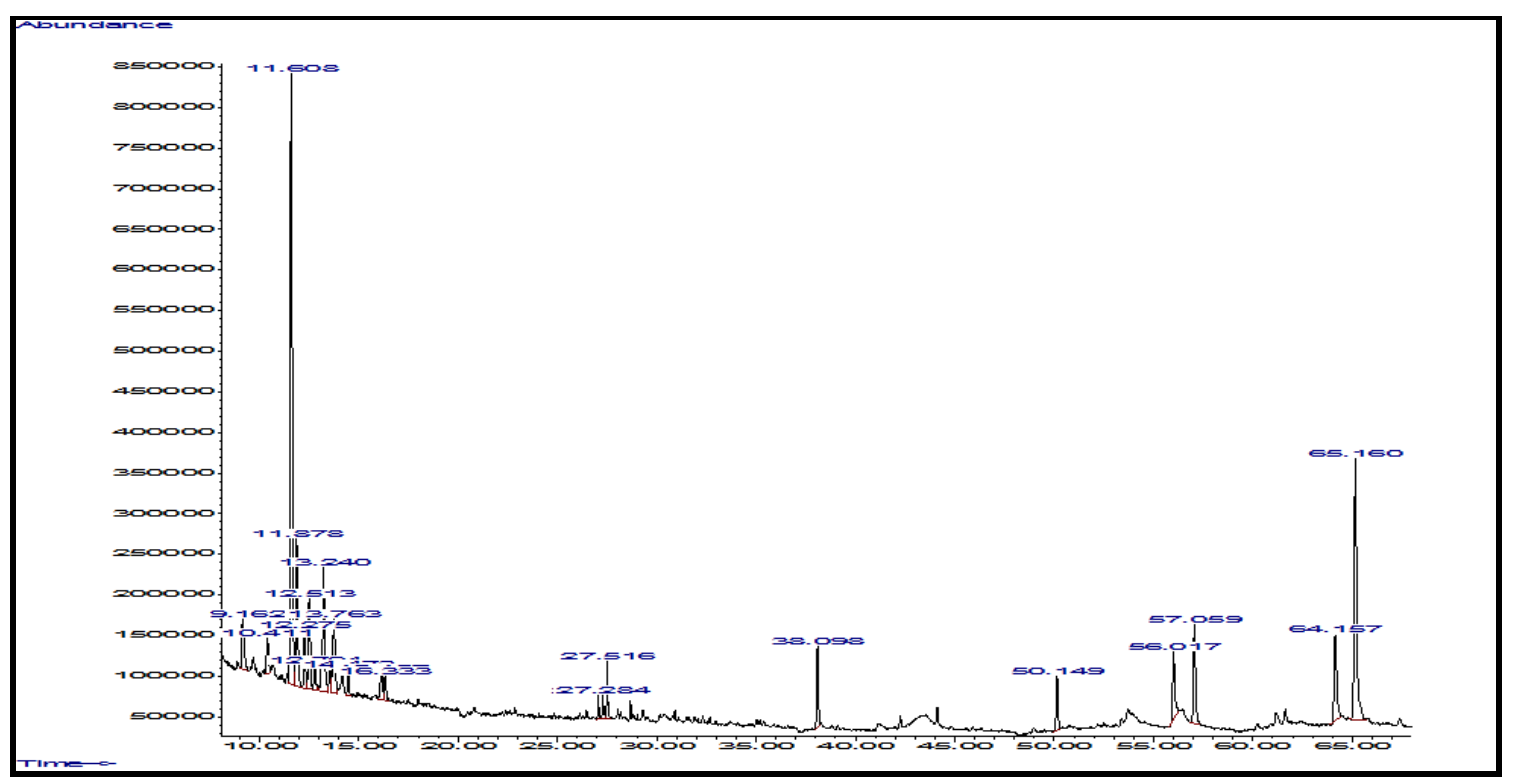

Figure 3. GC- MS chromatogram of the hexane fraction of compounds from Scutellaria Orientalis

Thirdly, twelve compounds were identified in Salvia palaestina by GC-MS analysis (Table 3). The list of phytochemical compounds from the plant sample is tabulated in Table 3 with retention time, area, and area percentage. The chromatogram information for the sample is given in Figure 4. 
The retention time taken by the bioactive compounds of the plant sample varied from 0.22 to 79.15 . It was found that main constituents of sample were trans-Caryophyllene $(1.43 \%)$, Neophytadiene $(0.22$ $\%)$, Sclareoloxide $(0.61 \%)$, geranyl-p-cymene $(0.22 \%)$, Caryophyllene (0.96 \%), 3-Aminophenol (1.47\%), Trichlorfon (79.15\%), Naphthalene, 1,2,3,4,4a,5,6,8a-octahydro-4a,8-dimethyl-2-(1methylet henyl)-, [2R (5.84\%), Allidochlor (0.25\%), Isobornyl thiocyanoacetate (1.03\%), Heptacosane $(0.64 \%)$, Nonacosane $(0.71 \%)$. Neophytadiene is an antipyretic, analgesic, anti-inflammatory, anti-microbial, antioxidant [42]. Sclareoloxide is known to demonstrate good antimicrobial activity, antioxidant and antiviral activities [43]. Geranyl-p-cymene has been reported that an antimicrobial, antioxidant, and antiproliferative effect [44]. Caryophyllene is also known as anticancer, antioxidant, and antimicrobial [45]. 3-Aminophenol is an antibacterial [46]. Trichlorfon is known for its insecticidal effects [47]. Naphthalene, 1,2,3,4,4a,5,6,8a-octahydro-4a,8-dimethyl-2-(1-methylet henyl)-, [2R is an insecticide, repellant [48]. Allidochlor is the more active herbicide and has been introduced into agricultural use [49]. Isobornyl thiocyanoacetate is an insecticide and used to control ants, houseflies, and head lice [50]. In this study, it was clearly demonstrated that Salvia palaestina has the potential to be used as an insecticidal because of the high rate of triclorfon in addition to the various therapeutic substances it contains.

Table 3. Phytochemical constituents of Salvia palaestina by GC-MS

\begin{tabular}{|c|c|c|c|c|c|c|}
\hline No & $\begin{array}{l}\text { Name of the } \\
\text { compound }\end{array}$ & $\begin{array}{l}\text { Molecular } \\
\text { formula }\end{array}$ & $\begin{array}{l}\text { Molecular } \\
\text { weight }\end{array}$ & RT & $\begin{array}{c}\text { Peak } \\
\text { area( } \\
\%)\end{array}$ & $\begin{array}{l}\text { Nature of the } \\
\text { compound }\end{array}$ \\
\hline 1 & trans-Caryophyllene & $\mathrm{C}_{15} \mathrm{H}_{24}$ & $204.35 \mathrm{~g} / \mathrm{mol}$ & 11.607 & 1.43 & Bicyclic sesquiterpene \\
\hline 2 & Neophytadiene & $\mathrm{C}_{20} \mathrm{H}_{38}$ & $278.5 \mathrm{~g} / \mathrm{mol}$ & 27.519 & 0.22 & Terpenes \\
\hline 3 & Sclareoloxide & $\mathrm{C}_{18} \mathrm{H}_{30} \mathrm{O}$ & $262.4 \mathrm{~g} / \mathrm{mol}$ & 28.049 & 0.61 & Diterpene \\
\hline 4 & geranyl-p-cymene & $\mathrm{C}_{18} \mathrm{H}_{26}$ & $242.4 \mathrm{~g} / \mathrm{mol}$ & 30.081 & 0.22 & Homoditerpenes \\
\hline 5 & Caryophyllene & $\mathrm{C}_{15} \mathrm{H}_{24}$ & $204.35 \mathrm{~g} / \mathrm{mol}$ & 32.986 & 0.96 & Bicyclic sesquiterpene \\
\hline 6 & 3-Aminophenol & $\mathrm{C}_{6} \mathrm{H}_{7} \mathrm{NO}$ & $109.13 \mathrm{~g} / \mathrm{mol}$ & 33.701 & 1.47 & Aminophenol \\
\hline 7 & Trichlorfon & $\mathrm{C}_{4} \mathrm{H}_{8} \mathrm{Cl}_{3} \mathrm{O}_{4} \mathrm{P}$ & $257.43 \mathrm{~g} / \mathrm{mol}$ & 38.481 & 79.15 & Phosphonic ester \\
\hline 8 & $\begin{array}{c}\text { Naphthalene, } \\
\text { 1,2,3,4,4a,5,6,8a- } \\
\text { octahydro-4a,8- } \\
\text { dimethyl-2-(1-methylet } \\
\text { henyl)-, [2R }\end{array}$ & $\mathrm{C}_{15} \mathrm{H}_{24}$ & $204.3511 \mathrm{~g} / \mathrm{mol}$ & 39.311 & 5.84 & Polycyclic hydrocarbon \\
\hline 9 & Allidochlor & $\mathrm{C}_{8} \mathrm{H}_{12} \mathrm{ClNO}$ & $173.64 \mathrm{~g} / \mathrm{mol}$ & 39.525 & 0.25 & Carboxamide \\
\hline 10 & $\begin{array}{l}\text { Isobornyl thiocyanoace- } \\
\text { tate }\end{array}$ & $\mathrm{C}_{13} \mathrm{H}_{19} \mathrm{NO}_{2} \mathrm{~S}$ & $253.36 \mathrm{~g} / \mathrm{mol}$ & 44.333 & 1.03 & $\begin{array}{c}\text { Thiocyanoacetic acid } \\
\text { ester }\end{array}$ \\
\hline 11 & Heptacosane & $\mathrm{C}_{27} \mathrm{H}_{56}$ & $380.7 \mathrm{~g} / \mathrm{mol}$ & 57.069 & 0.64 & N-Alkanes \\
\hline 12 & Nonacosane & $\mathrm{C}_{29} \mathrm{H}_{60}$ & $408.8 \mathrm{~g} / \mathrm{mol}$ & 65.168 & 0.71 & N-Alkanes \\
\hline
\end{tabular}




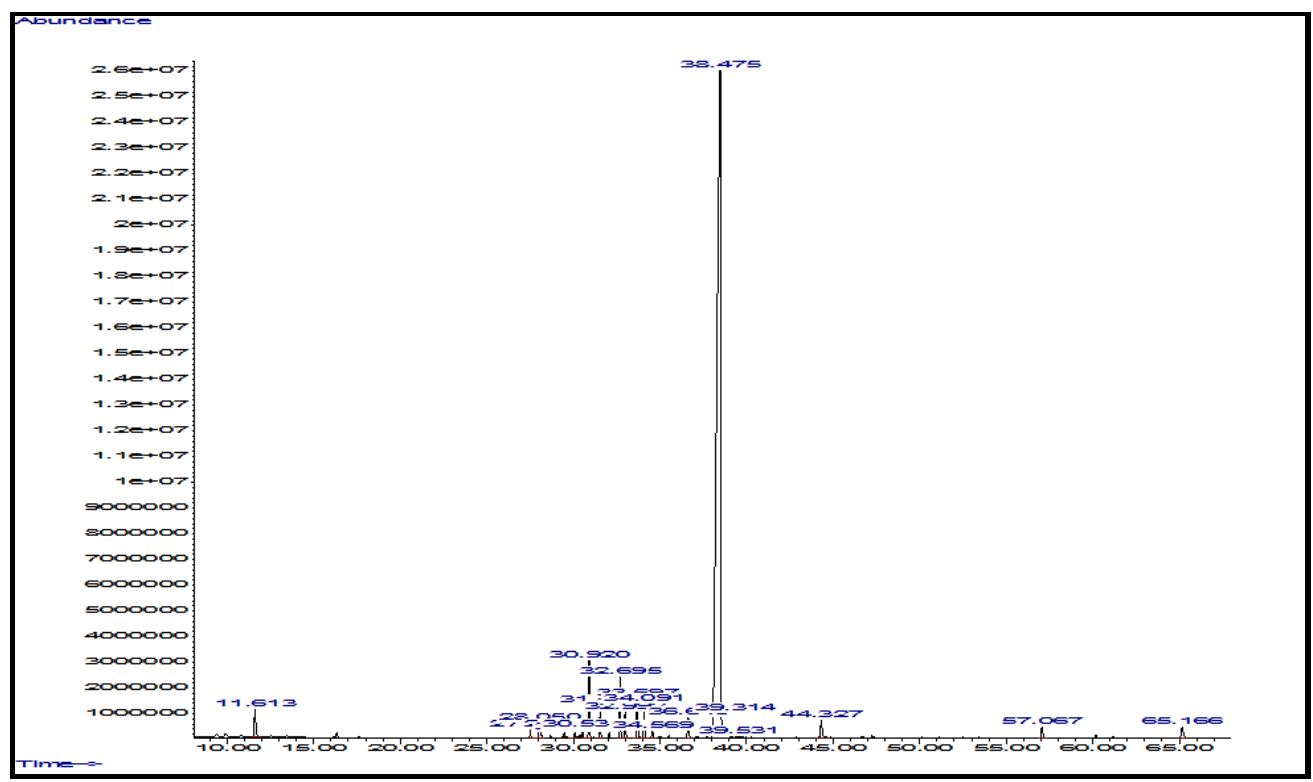

Figure 4. GC- MS chromatogram of the hexane fraction of compounds from Salvia palaestina

\section{Conclusion}

Today, more than 5000 phytochemicals have been discovered, although it varies according to plant species, most of them have not been identified yet. From current research, Salvia palaestina, Alkanna trichophila var. mardinensis, Scutellaria orientalis samples (whole plant parts) revealed that they constitute a wide range of bioactive phytochemicals with high therapeutic value. Especially, triclorfon, bis (2-ethylhexyl) pht-halate (DEHP), trans-caryophyllene molecules were found in large amounts, showing that these plants are candidate drug plant that can be used for a apoptosis inhibitor, an androstane receptor agonist and a plasticizer, anti-leukaemic, anti-mutagenic, antimicrobial and cytotoxic activity, insecticide, antibacterial and antifungal purposes. However, we are of the opinion that isolation of individual phytochemical components and subjecting them to pharmacological activity would certainly yield fruitful results.

The compliance to the Research and Publication Ethics: This study was carried out in accordance with the rules of research and publication ethics.

\section{References}

[1] Güner, A., Özhatay, N., Ekim, T., Başer, KHC. (editors). Flora of Turkey and the East Aegean Islands (Suppl. 2), Vol. 11. Edinburgh, UK: Edinburgh University Press. 2000.

[2] Acıbuca, V and Bostan, Budak D., "Dünya'da ve Türkiye'de Trbbi ve Aromatik Bitkilerin Yeri ve Önemi”, Çukurova Journal of Agricultural and Food Sciences, 33(1), 37-44, 2018.

[3] Başer, H.C., "Sustainable Wild Harvesting of Medicinal and Aromatic Plants: An Educational Approach, Harvesting On Non-Wood Forest Products", Seminar Proceedings, Menemen-İzmir, Turkey, 2000.

[4] Bayramoğlu, M.M, Toksoy, D., Şen, G., “Türkiye’de Tibbi Bitki Ticareti”, II. Ormanc1lıkta Sosyo-Ekonomik Sorunlar Kongresi, 19-21 Şubat, SDÜ, Isparta, 2009.

[5] Mojab, F., Kamalinejad, M., Ghaderi, N., Vahidipour, H.R,. "Phytochemical screening of some species of Iranian plants", Iranian Journal of Pharmaceutical Research, 2(2), 77-82, 2003. 
[6] Davis, P.H., Milli, R.R., Kit, Tan., Flora of Turkey and The East Aegean Island (Supplement), Edinburgh Univ. Press., Vol. 10, Edinburgh, 1988.

[7] Davis, P.H., Flora of Turkey and The Aegean Islands, University Pres, Vol: VI, Edinburg, 1978.

[8] Wei, G., Hui, C., Lin, K., Xue-ru, L., Chao-ying, M. and He-zhong, J., “ Composition And Bioactivity of the Essential Oil from the Leaves of Lindera setchuenensis", Chemistry of Natural Compounds, 52 (3), 520-522, 2016.

[9] Molnár, P. B., Csengele, B., Erdei, A. L., Takeshi, F., Pál, V., Katalin, J. J. And Kárpáti, Z., “ Identification of the Female-Produced Sex Pheromone of an Invasive Greenhouse Pest, the European Pepper Moth (Duponchelia fovealis)", Journal of Chemical Ecology, 44, 257-267, 2018.

[10] Teal, J. P. E.A., . Tumlinson, R. H.. Heath, R., "Chemical and behavioral analyses of volatile sex pheromone components released by calling Heliothis virescens (F.) females (Lepidoptera: Noctuidae)", Journal of Chemical Ecology, 12 (1), 107-126, 1986.

[11] Ulitzur, S. and Hastings, J. W., "Evidence for tetradecanal as the natural aldehyde in bacterial bioluminescence". Proceedings of the National Academy of Sciences of the United States of America, 76(1), 265-267, 1979.

[12] Chung, I.M., Ahmad, A., Kim, S.J., Naik, P.M., Nagella, P., "Composition of the essential oil constituents from leaves and stems of Korean Coriandrum sativum and their immunotoxicity activity on the Aedes aegypti L.", Immunopharmacology and Immunotoxicology, 34(1), 152-6, 2012.

[13] Černohlávková, J., Jarkovský, J., Jiří, H., "Effects of fungicides mancozeb and dinocap on carbon and nitrogen mineralization in soils", Ecotoxicology and Environmental Safety, 72 (1), 80$85,2009$.

[14] Habib, M. R., Karim, M. R. "Antimicrobial and Cytotoxic Activity of Di-(2-ethylhexyl) Phthalate and Anhydrosophoradiol-3-acetate Isolated from Calotropis gigantea (Linn.) Flower", Journal Mycobiology, 37 (1), 31-36, 2009.

[15] Lee, K. H., Kim, J. H., Lim, D. S., Kim, C. H., "Anti-leukaemic and Anti-mutagenic Effects of Di(2-ethylhexyl)phthalate Isolated from Aloe vera Linne", Journal of Pharmacy and Pharmacology, https://doi.org/10.1211/0022357001774246, 2010.

[16] Otuki, M. F., Ferreira, J., Lima, F. V., Meyre-Silva, C., Malheiros, A., Muller, L. A., Cani, G.S., Santos, A. R.S., Yunes, R. A., Calixto, J. B., "Antinociceptive properties of mixture of alphaamyrin and beta-amyrin triterpenes: evidence for participation of protein kinase $\mathrm{C}$ and protein kinase A pathways", Journal of Pharmacology and Experimental Therapeutics, 313(1), 310318, 2005.

[17] Pinto, S. A. H., Pinto, L. M. S., Guedes, M. A., Cunha, G. M. A., Chaves, M. H., Santos, F. A., Rao, V. S., "Antinoceptive effect of triterpenoid alpha,beta-amyrin in rats on orofacial pain induced by formalin and capsaicin", Phytomedicine, 15(8), 630-634, 2008.

[18] Ma, J., Lu, N., Qin, W., Xu, R., Wang, Y., Chen, X., "Differential responses of eight cyanobacterial and green algal species, to carbamate insecticides", Ecotoxicology and Environmental Safety, 63 (2), 268-274, 2006.

[19] Bakthavatsalam, N., Tandon, P.L., Bhagat, D., Trichogrammatids: Behavioural Ecology”. In: Sithanantham S., Ballal C., Jalali S., Bakthavatsalam N. (eds) Biological Control of Insect Pests 
Using Egg Parasitoids. Springer, New Delhi. https://doi.org/10.1007/978-81-322-1181-5_5., 2013.

[20] Tao, C., Wu, J., Liu, Y., Liu, M., Yang, R. and Zhaolin Lv., “Antimicrobial activities of bamboo (Phyllostachys heterocycla cv. pubescens) leaf essential oil and its major components", European Food Research and Technology, 244, 881-891, 2018.

[21] Khatua, S., Pandey, A. and Biswas, S. J., "Phytochemical evaluation and antimicrobial properties of Trichosanthes dioica root extract", Journal of Pharmacognosy and Phytochemistry, 5(5), 410-413, 2016.

[22] Bakr, R. O., El-Naa, M. M., Zaghloul, S. S. and Omar, M. M., BMC Complementary Medicine and Therapies, 17, 1-13, 2017.

[23] Paul, A.V.N., Singh, S. and Singh, A.K. "Kairomonal effect of some saturated hydrocarbons on the egg parasitoids, Trichogramma brasiliensis (Ashmead) and Trichogramma exiguum (Hymenoptera: Trichogrammatidae)", Journal of Applied Entomology, 126, 409-416, 2002.

[24] Rizwan, K., Zubair, M , Rasool, N. , Riaz, M., Zia-Ul-Haq, M. and de Feo, V., "Phytochemical and Biological Studies of Agave attenuata", International Journal of Molecular Sciences, 13, 6440-6451, 2012.

[25] Gumgumjee, N.M. and Hajar, S.A. "Antibacterial activities and GC-MS analysis of phytocomponents of Ehretia abyssinica R.Br. ex fresen" International Journal of Applied Biology and Pharmaceutical Technology, 6(2), 236-241, 2015.

[26] Habib, R., Karim M. R., "Antitumour evaluation of di-(2-ethylhexyl) phthalate (DEHP) isolated from Calotropis gigantea L. flower“, Acta Pharmaceutica, 62(4), 607-615, 2012.

[27] Drapeau, J., Verdier, M., Touraud, D., Kröckel, U., Geier, M., Rose, A., Kunz, W., "Effective insect repellent formulation in both surfactantless and classical microemulsions with a longlasting protection for human beings", Chemistry \& biodiversity, 6(6), 934-47, 2009.

[28] Accession adress: "http://fses.oregonstate.edu/", accession date 01.12.2020.

[29] Öztürk, M., Duru, M. E., Aydoğmuş-Öztürk, F., Harmandar, M. , Mahlıçlı, M., Kolak, U. and Ulubelen, A., "GC-MS Analysis and Antimicrobial Activity of Essential Oil of Stachys cretica subsp. smyrnaea", Natural Product Communications, 4 (1), 109-114, 2009.

[30] Park, S,Y, Park, S.J., Park, N.J., Joo, W.H., Lee, S.J., Choi, Y.W., “ $\alpha$-Iso-cubebene exerts neuroprotective effects in amyloid beta stimulated microglia activation", Neuroscience Letters, Oct 25;555:143-148. doi: 10.1016/j.neulet. 09.053, 2013.

[31] Kwon, B., Shin, H., Moon, H.B., Ji, K., Kim, K.T., "Effects of tris(2-butoxyethyl) phosphate exposure on endocrine systems and reproduction of zebrafish (Danio rerio)", Environmental Pollution, 214, 568-574, 2016.

[32] Sharififar, F., Mozaffarian, V., Moradkhani, S., "Comparison of antioxidant and free radical scavenging activities of the essential oils from flowers and fruits of Otostegia persica Boiss", $\mathrm{Pa}$ kistan Journal of Biological Sciences, 10(21), 3895-3899, 2007.

[33] Lin, X.H., Wu, Y.B., Lin, S. Zeng, J.W., Zeng, P.Y., Wu, J.Z. "Effects of volatile components and ethanolic extract from Eclipta prostrata on proliferation and differentiation of primary osteoblasts", Molecules, 15(1), 241-50, 2010. 
[34]Sivasubramanian, R. and Brindha, P. "In- vitro cytotoxic, antioxidant and GC-MS studies on Centratherum punctatum cass.", International Journal of Pharmacy and Pharmaceutical Sciences, 5( 3), 364-367, 2013.

[35] Islam, S., Firoz, M., "Triacontanol as a dynamic growth regulator for plants under diverse environmental conditions ”, Physiology and Molecular Biology of Plants, 26(5), 871-883, 2020.

[36] Kuiate, J.R., Bessière, J.M., Zollo, P.H., Kuate, S.P., "Chemical composition and antidermatophytic properties of volatile fractions of hexanic extract from leaves of Cupressus lusitanica Mill. from Cameroon", Journal of Ethnopharmacology, 103(2), 160-165, 2006.

[37] Kumar, S., Malhotra, R., Kumar, D., "Euphorbia hirta: Its chemistry, traditional and medicinal uses, and pharmacological activities", Pharmacognosy Reviews, , 4(7), 58-61, 2010.

[38] Jemia, M.B., Formisano, C., Bancheva, S., Bruno, M., Senatore, F., "Chemical composition of the essential oils of Centaurea formanekii and C. orphanidea ssp. thessala, growing wild in Greece", Natural product communications, 7(8), 1083-1086, 2012.

[39] Begum, I., Faridha, R., Mohankumar, M., Jeevan, Ramani, K., "GC-MS Analysis of Bio-active Molecules Derived from Paracoccus pantotrophus FMR19 and the Antimicrobial Activity Against Bacterial Pathogens and MDROs”, Indian Journal of Microbiology,56(4), 426-432, 2016.

[40] Zakariaa, M.B., Vijayasekarana, Ilhama, Z. and Muhamad, N.A., "Anti-Inflammatory Activity of Calophyllum inophyllum Fruits Extracts”, Procedia Chemistry, 13, 218-222, 2014.

[41] Köse, Y.B., Iscan, G. and Demirci, B., "Antimicrobial Activity of the Essential Oils Obtained from Flowering Aerial Parts of Centaurea lycopifolia Boiss. et Kotschy and Centaurea cheirolopha (Fenzl) Wagenitz from Turkey”, Journal of Essential Oil Bearing Plants, 19(3), 762 768, 2016.

[42] Yamuna, P., Abirami, P., Vijayashalini, P. and Sharmila, M., "GC-MS analysis of bioactive compounds in the entire plant parts of ethanolic extract of Gomphrena decumbens Jacq.", Journal of Medicinal Plants Studies, 5(3), 31-37, 2017.

[43] Ögütçü, H., Sökmen, A., Sökmen, M., Polissiou, M., Serkedjieva, J., Daferera, D., Şahin, F., Barış, Ö., Güllüce, M. "Bioactivities of the Various Extracts and Essential Oils of Salvia limbata C.A.Mey. and Salvia sclarea L.” Turkish Journal of Biology, 32, 181-192, 2008.

[44] Mitropoulou, G., Sidira, M., Skitsa, M., Tsochantaridis, I., Pappa, A., Dimtsoudis, C., Proestos, C. And Kourkoutas, Y., "Assessment of the Antimicrobial, Antioxidant, and Antiproliferative Potential of Sideritis raeseri subps. Raeseri Essential Oil", Foods, 9(7), 860, 2020.

[45] Dahham, S. S., Tabana, Y. M., Iqbal, M. A., Ahamed, M. B. K., Ezzat, M.O., Aman, S. A. M. and Amin, M. S. A. M., "The Anticancer, Antioxidant and Antimicrobial Properties of the Sesquiterpene $\beta$-Caryophyllene from the Essential Oil of Aquilaria crassna", Molecules, 20(7), 11808$11829,2015$.

[46] Adamu, U. A., Magaji, B., Ibrahim, M. N. and San, M. M., "Synthesis, Characterization and Antibacterial Evaluation of Mn (II), Co (II) and Cu (II) Complexes of Schiff Base Derived from 3aminophenol and Benzaldehyde", Asian Journal of Chemical Sciences, 7(2), 39-44, 2020.

[47] Dunier, M., Siwicki, Andrzej K., Demaël, A., "Effects of organophosphorus insecticides: Effects of trichlorfon and dichlorvos on the immune response of carp (Cyprinus carpio): III. In Vitro effects on lymphocyte proliferation and phagocytosis and in vivo effects on humoral response". Ecotoxicology and Environmental Safety, 22 (1), 79-87, 1991. 
[48] Daisy, B. H., Strobel, G. A., Castillo, U., Ezra, D., Sears, J. , Weaver, D. K., Runyon, J. B., "Naphthalene, an insect repellent, is produced by Muscodor vitigenus, a novel endophytic fungus", Microbiology (Reading), 148 (11), 3737-3741, 2002.

[49] Matolcsy, G., Nádasy, M., Andriska, V., Pesticide chemistry,.Amsterdam-Oxford-New YorkTokyo, 551, 1988.

[50] Accession adress: https://drugs.ncats.io/drug/, accession date 01.12.2020. 